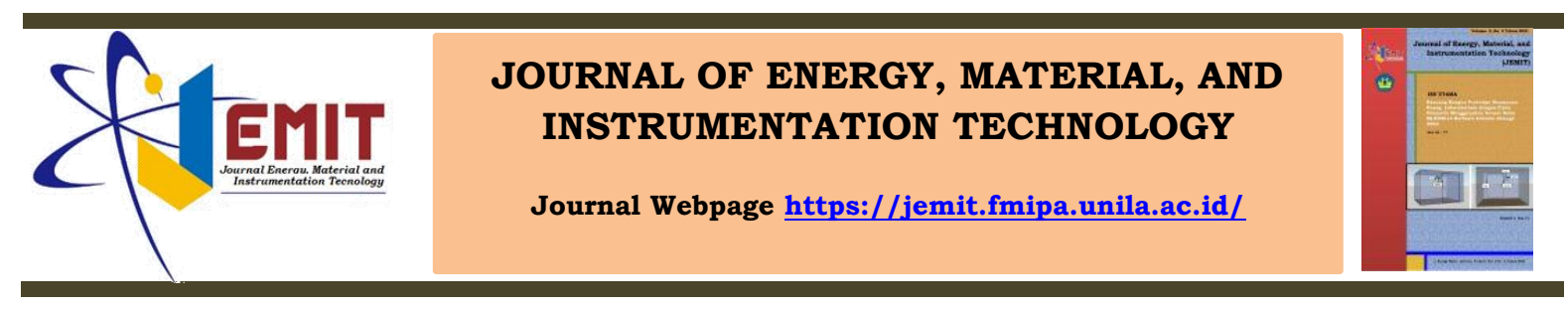

\title{
Analisis Pertumbuhan Fase Superkonduktor BSCC0-2212 dan BPSCC0-2212 Akibat Variasi Suhu Sintering Menggunakan Metode Pencampuran Basah
}

\author{
Pulung Karo Karo(a,*), Risky Putra Ramadhan, Suprihatin ${ }^{(b)}$, dan Yanti Yulianti \\ Jurusan Fisika, Universitas Lampung, Bandar Lampung, Indonesia, 35141
}

\begin{tabular}{|c|c|}
\hline Article Information & Abstract \\
\hline $\begin{array}{l}\text { Article history: } \\
\text { Received October } 26^{\text {th }}, 2021 \\
\text { Received in revised form } \\
\text { November } 5^{\text {th }}, 2021 \\
\text { Accepted November } 2^{\text {th }} \text {, } \\
2021\end{array}$ & $\begin{array}{l}\text { The research was conducted to determine the effect of sintering temperature on } \\
\text { the level of purity of the superconducting phase BSCCO-2212 and BPSCCO- } \\
2212 \text { using the wet mixing method. Sintering was carried out for } 20 \text { hours with } \\
\text { variations in sintering temperature: } 825,830,835 \text { and } 840^{\circ} \mathrm{C} \text {. XRD results } \\
\text { showed that the phase purity level increased until it reached the optimum point } \\
\text { at } 835^{\circ} \mathrm{C} \text { sintering temperature and then decreased at } 840^{\circ} \mathrm{C} \text {. The highest } \\
\text { volume fraction of the BSCCO- } 2212 \text { sample was obtained at a sintering } \\
\text { temperature of } 8355^{\circ} \mathrm{C} \text { at } 71.09 \% \text { and the highest degree of orientation was } \\
\text { obtained at a sintering temperature of } 830^{\circ} \mathrm{C} \text { at } 26.44 \% \text {. In the BPSCCO- } 2212 \\
\text { sample, the highest volume fraction was obtained at a sintering temperature of } \\
835^{\circ} \mathrm{C} \text { at } 52.59 \% \text { and the highest degree of orientation at a sintering } \\
\text { temperature of } 830^{\circ} \mathrm{C} \text { at } 43.49 \% \text {. The optimum value of the volume fraction of } \\
\text { BSCCO- } 2212 \text { is higher than that of BPSCCO-2212. While the optimum value of } \\
\text { the degree of orientation of BPSCCO-2212 is higher than that of BSCCO-22 } 12\end{array}$ \\
\hline Informasi Artikel & Abstrak \\
\hline $\begin{array}{l}\text { Proses artikel: } \\
\text { Diterima } 26 \text { Oktober } 2021 \\
\text { Diterima dan direvisi dari } 5 \\
\text { November } 2021 \\
\text { Accepted } 29 \text { November } 2021\end{array}$ & $\begin{array}{l}\text { Penelitian dilakukan untuk mengetahui pengaruh suhu sintering terhadap } \\
\text { tingkat kemurnian fase superkonduktor BSCCO-2212 dan BPSCCO-2212 } \\
\text { menggunakan metode pencampuran basah. Sintering dilakukan selama } 20 \text { jam } \\
\text { dengan variasi suhu sintering: 825, 830, 835 dan } 840^{\circ} \mathrm{C} \text { Hasil XRD } \\
\text { menunjukkan tingkat kemurnian fase meningkat hingga mencapai titik optimum } \\
\text { pada suhu sintering } 835^{\circ} \mathrm{C} \text { kemudian mengalami penurunan pada suhu } \\
\text { sintering } 840^{\circ} \mathrm{C} \text {. Fraksi volume tertinggi sampel BSCCO-2212 didapatkan pada } \\
\text { suhu sintering } 835^{\circ} \mathrm{C} \text { sebesar } 71,09 \% \text { dan derajat orientasi tertinggi } \\
\text { didapatkan pada suhu sintering } 830^{\circ} \mathrm{C} \text { sebesar } 26,44 \% \text {. Pada sampel BPSCCO- } \\
2212 \text { fraksi volume tertinggi didapatkan pada suhu sintering } 835^{\circ} \mathrm{C} \text { sebesar } \\
52,59 \% \text { dan derajat orientasi tertinggi pada suhu sintering } 830^{\circ} \mathrm{C} \text { sebesar } \\
43,49 \% \text { Nilai optimum fraksi volume BSCCO-2212 lebih tinggi dari pada } \\
\text { BPSCCO-2212. Sedangkan nilai optimum derajat orientasi BPSCCO-2212 lebih } \\
\text { tinggi dari pada BSCCO-2212 }\end{array}$ \\
\hline
\end{tabular}

\section{Pendahuluan}

Material superkonduktor sangat berperanan penting dalam perkembangan teknologi saat ini. Superkonduktor merupakan matarial dengan resistivitas bernilai nol ketika berada di bawah suhu kritisnya sehingga dapat menghantarkan arus listrik tanpa hambatan. Dalam pembuatan material superkonduktor terdapat empat metode sintesis, diantaranya metode sol gel, metode lelehan, metode padatan, dan metode pencampuran basah.

Salah satu contoh material superkonduktor dengan suhu kritis tinggi yaitu superkonduktor sistem BSCCO. Superkonduktor sistem BSCCO merupakan superkonduktor oksida keramik yang memiliki keunggulan suhu kritis yang tinggi dan tidak mengandung unsur beracun. Sistem BSCCO memiliki 3 fase yaitu Bi-2201 dengan Tc $10^{\circ} \mathrm{K}$, $\mathrm{Bi}-2212$ dengan $\mathrm{Tc} 80^{\circ} \mathrm{K}$, Bi-2223 dengan Tc $110^{\circ} \mathrm{K}$. 
Dalam pembuatan superkonduktor sistem BSCCO terdapat beberapa faktor yang dapat meningkatkan suhu kritis dan kemurnian fase, misalnya penambahan doping $\mathrm{Pb}$, variasi waktu dan suhu sintering dan variasi kadar Ca. Suhu sintering dapat mempercepat pertumbuhan fase dan pembentukan struktur kristal.

Kemurnian fase juga dapat ditingkatkan dengan penambahan doping $\mathrm{Pb}$. Doping $\mathrm{Pb}$ digunakan karena $\mathrm{Pb}$ memiliki ukuran atom dan nomor valensi yang mirip dengan unsur Bi sehingga mampu mensubtitusi posisi Bi pada sistem $\mathrm{BSCCO}$. Penambahan doping $\mathrm{Pb}$ juga meningkatkan derajat orientasi.

Dari latar belakang tersebut, dilakukan penelitian pengaruh variasi suhu sintering terhadap superkonduktor BSCCO-2212 dan BPSCCO-2212 menggunakan metode pencampuran basah. Aspek yang dipelajari dalam penelitian ini adalah tingkat kemurnian fase yang terbentuk berdasarkan fraksi volume, derajat orientasi dan impuritas. Hasil yang diperoleh kemudian dikarakterisasi menggunakan X-Ray Diffraction (XRD) selanjutnya dianalisi menggunakan program highscore plus (HSP).

\section{Metode Penelitian}

Penelitian menggunakan bahan $\mathrm{Bi}_{2} \mathrm{O}_{3}(99,9 \%)$ dari Strem Chemical; $\mathrm{SrCO}_{3}$ (99,9\%) dari Strem Chemical; $\mathrm{CaCO}_{3}$ (99,9\%) dari Strem Chemical; dan $\mathrm{CuO}$ (99,99\%) dari Merck, dan PbO (99\%) dari Aldrick. Bahan dasar tersebut kemudian ditimbang untuk membuat tiga gram sampel BSCCO-2212 dan tiga BPSCCO-2212 ditunjukkan pada Tabel 1 dan Tabel 2.

Tabel 1. Komposisi bahan BSCCO-2212

\begin{tabular}{lcc}
\hline Bahan & Fraksi Mol & Massa Bahan \\
\hline $\mathrm{Bi}_{2} \mathrm{O}_{3}$ & 2,0 & 1,3699 \\
$\mathrm{SrCO}_{3}$ & 2,0 & 0,8681 \\
$\mathrm{CaCO}_{3}$ & 1,1 & 0,2943 \\
$\mathrm{CuO}$ & 2,0 & 0,4677 \\
\hline Total & & 3,0000 \\
\hline
\end{tabular}

Tabel 2. Komposisi bahan BPSCCO-2212

\begin{tabular}{lcc}
\hline Bahan & Fraksi Mol & Massa Bahan \\
\hline $\mathrm{Bi}_{2} \mathrm{O}_{3}$ & 1,8 & 1,2353 \\
$\mathrm{PbO}$ & 0,2 & 0,1315 \\
$\mathrm{SrCO}_{3}$ & 2,0 & 0,8697 \\
$\mathrm{CaCO}_{3}$ & 1,1 & 0,2948 \\
$\mathrm{CuO}$ & 2,0 & 0,4686 \\
\hline Total & & 3,0000 \\
\hline
\end{tabular}

Setelah ditimbang, sampel dilarutkan dalam asam nitrat $\left(\mathrm{HNO}_{3}\right) 68 \%$ dan aquades hingga larutan berwarna biru jernih. Selanjutnya sampel dipanaskan menggunakan hot plate selama $5-6$ jam dengan suhu $70^{\circ} \mathrm{C}$. Sampel kemudian dikeringkan pada suhu 300,400 dan $600^{\circ} \mathrm{C}$ secara bertahap menggunakan furnace.

Sampel digerus menggunakan mortar dan pastle selama \pm 10 jam sampai terasa halus. Kemudian dilakukan kompaksi menggunakan alat pressing dengan kuat tekan 8 ton. Setelah sampel menjadi pelet, selanjutnya di kalsinasi pada suhu $800^{\circ} \mathrm{C}$ selama 10 jam.

Sampel hasil kalsinasi belum sempurna karena adanya porositas, sehingga harus dilakukan penggerusan ulang. Selanjutnya dilakukan sintering dengan variasi suhu $825,830,835$ dan $840^{\circ} \mathrm{C}$ selama 20 jam. Diagram alir penelitian ditampilkan pada Gambar 1.

Hasil sintesis kemudian dikarakterisasi menggunakan X-Ray Diffraction (XRD). Karakterisasi XRD dilakukan untuk mengetahui tingkat kemurnian fase berdasarkan fraksi volume $(F v)$, derajat orientasi $(P)$, dan Impuritas $(I)$ menggunakan persamaan:

$$
\begin{aligned}
& F v=\frac{\sum I(2212)}{\sum I(\text { total })} \times 100 \% \\
& P=\frac{\sum I(00 l)}{\sum I(2212)} \times 100 \% \\
& I=100 \%-F v
\end{aligned}
$$


Karo P K, Ramadhan R P, Suprihatin, dan Yulianti Y, 2021, Analisis Pertumbuhan Fase Superkonduktor BSCCO2212 dan BPSCCO-2212 Akibat Variasi Suhu Sintering Menggunakan Metode Pencampuran Basah, Journal of Energy, Material, and Instrumentation Technology, Vol. 2, No. 4, 2021

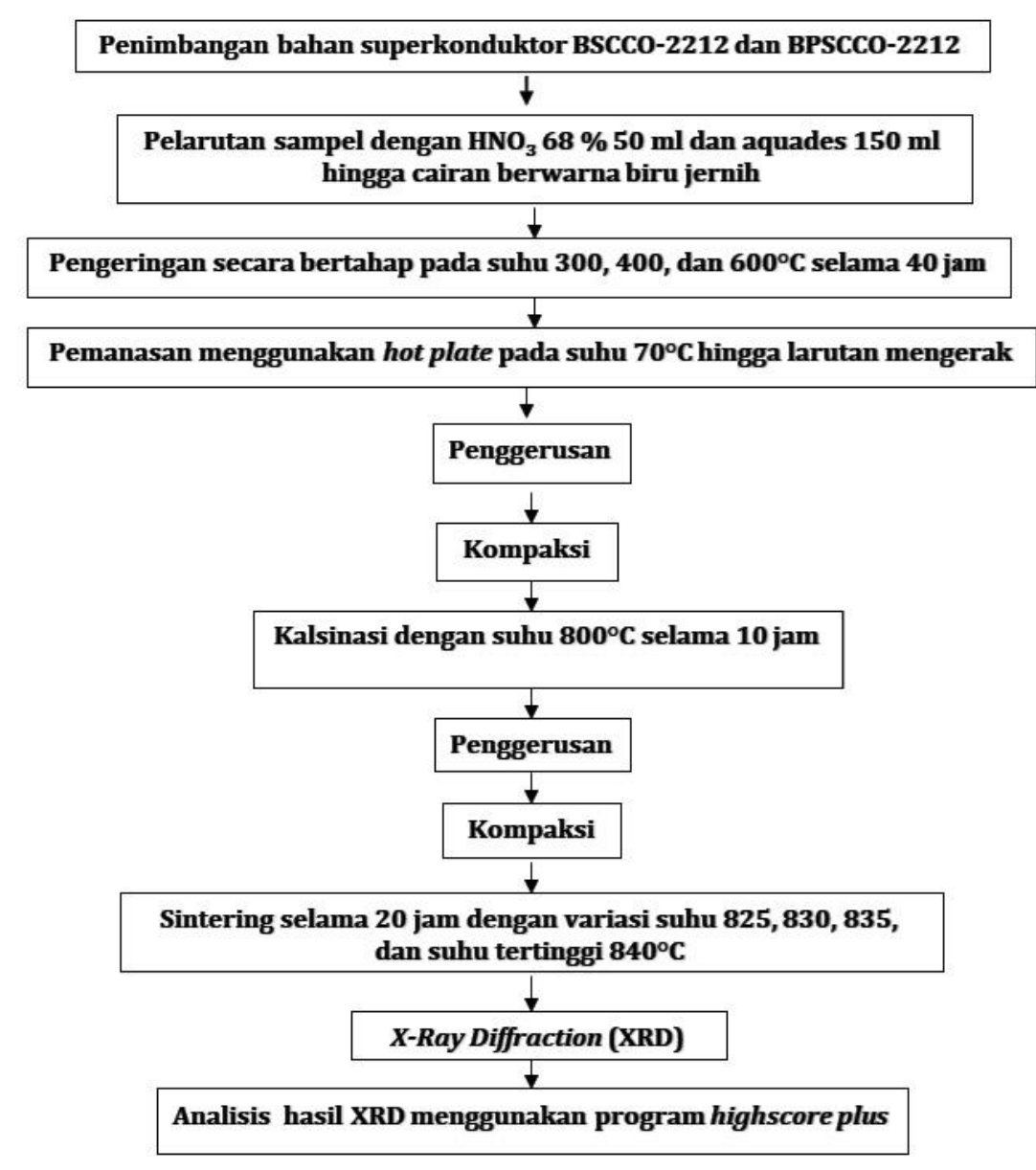

Gambar 1. Diagram alir penelitian.

\section{Hasil dan Pembahasan}

\subsection{Hasil Analisis X-Ray Diffraction (XRD) BSCCO-2212}

Karakterisasi XRD dilakukan untuk mengetahui tingkat kemurnian fase yang terbentuk dalam sampel dengan menghitung fraksi volume, derajat orientasi dan impuritasnya. Hasil karakterisasi XRD dianalisis menggunakan program highscore plus (HSP) untuk mengetahui fase yang terbentuk. Pada sampel BSCCO-2212 menunjukkan terbentuknya fase $\mathrm{BSCCO}-2212, \mathrm{CaCuO}_{2}$, dan $\mathrm{CuO}_{2}$ sesuai dengan diagram fase superkonduktor Strobel et al (1992). Selain itu terbentuk juga fase lain sebagai impuritas. Banyaknya fase yang terbentuk disebabkan karena bahan pembentuk superkonduktor memiliki titik leleh yang berbeda, sehingga menyebabkan berkurangnya beberapa unsur - unsur saat dipanaskan pada suhu tinggi. Hasil analisis XRD sampel BSCCO-2212 ditunjukkan pada Gambar 2. 


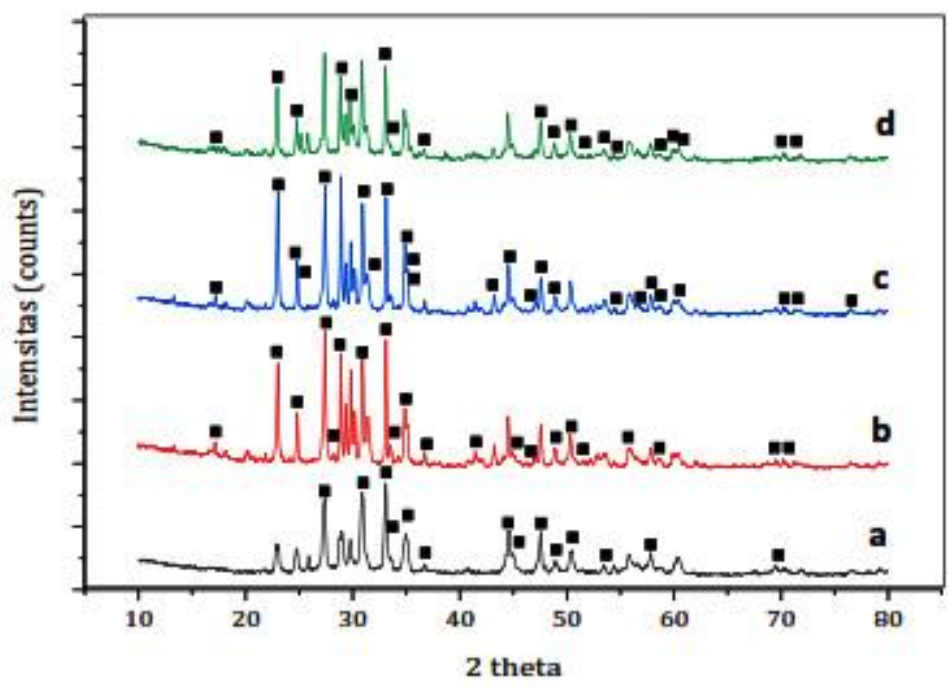

Gambar 2 Hasil analisis XRD sampel BSCCO-2212 menggunakan HSP ( $\mathbf{a}=$ fase BSCCO-2212). a (BSCCO-2212825), b (BSCCO-2212-830), c (BSCCO-2212-835), dan d (BSCCO-2212-840). pada Tabel 3

Hasil perhitungan fraksi volume $(F v)$, impuritas (I) dan derajat orientasi $(P)$ BSCCO-2212 ditunjukkan

Tabe1 3. Hasil perhitungan tingkat kemurnian fase BSCCO- 2212 akibat variasi suhu sintering

Kode Sampel

Suhu $\left({ }^{\circ} \mathrm{C}\right)$

Fraksi Volume (\%)

Impuritas (\%)
Derajat Orientasi

(\%)

\begin{tabular}{lcccc}
\hline BSCCO-2212-825 & 825 & 51,91 & 48,09 & 8,49 \\
BSCCO-2212-830 & 830 & 60,33 & 39,67 & 26,44 \\
BSCCO-2212-835 & 835 & 71,09 & 28,91 & 18,25 \\
BSCCO-2212-840 & 840 & 49,68 & 50,32 & 12,43 \\
\hline
\end{tabular}

Berdasarkan hasil perhitungan yang diperoleh terjadi peningkatan nilai fraksi volume hingga mencapai suhu $835^{\circ} \mathrm{C}$ kemudian terjadi penurunan pada suhu $840^{\circ} \mathrm{C}$ seperti yang ditunjukkan pada Tabel 3.

Pada sampel BSCCO-2212 nilai $F v$ mencapai titik optimum pada suhu sintering $835^{\circ} \mathrm{C}$ sebesar $71,09 \%$ dan $I$ sebesar 28,91\% dengan impuritas merupakan fase $\mathrm{Bi}_{2} \mathrm{Sr}_{2} \mathrm{CuO}_{x}, \mathrm{CaCuO}_{2}, \mathrm{CuO}, \mathrm{Ca}_{4} \mathrm{O}_{4} \mathrm{dan} \mathrm{Sr}_{2} \mathrm{Cu}_{2} \mathrm{O}_{3}$. Sedangkan nilai $\mathrm{Fv}$ terendah terdapat pada suhu sintering $840^{\circ} \mathrm{C}$ sebesar $49,68 \%$ dan $I$ sebesar $50,32 \%$ dengan impuritas merupakan fase $\mathrm{CaCuO}_{2}, \mathrm{CaBi}_{2} \mathrm{O}_{4}, \mathrm{Sr}_{8,5} \mathrm{Bi}_{6} \mathrm{Ca}_{2,5} \mathrm{O}_{22}$ dan $\mathrm{Bi}_{2} \mathrm{Sr}_{2} \mathrm{Ca}_{2} \mathrm{Cu}_{3} \mathrm{O}_{\mathrm{x}}$. Suhu sintering 825 menghasilkan nilai $F v$ sebesar $51,91 \%$ dan $I$ sebesar $48,09 \%$ dengan impuritas merupakan fase $\mathrm{Bi}_{2} \mathrm{Sr}_{2} \mathrm{CuO}_{\mathrm{x}}$, $\mathrm{CaCuO}_{2}, \mathrm{CuO}_{2}$, dan $\mathrm{Bi}$. Suhu sintering 830 menghasilkan $F v$ sebesar 60,33\% dan I sebesar 39,67\% dengan impuritas merupakan fase $\mathrm{CaCuO}_{2}, \mathrm{CuO}, \mathrm{CaSr}_{3} \mathrm{Bi}_{2} \mathrm{O}_{89}$ dan, $\mathrm{Ca}_{4} \mathrm{O}_{4}$.

Kemudian diperoleh juga hasil perhitungan derajat orientasi berupa nilai puncak $h=k=0$ dan $l$ merupakan bilangan genap. Hasil perhitungan $P$ menghasilkan nilai $P$ tertinggi pada suhu sintering $830^{\circ} \mathrm{C}$ sebesar $26,44 \%$ didapat dari $2 \theta=17,2083$ dengan $h k l=(006), 2 \theta=23,0308$ dengan $h k l=(008), 2 \theta=28,9067$ dengan $h k l=$ $(00 \underline{10}), 2 \theta=34,8559$ dengan $h k l=(0012)$ dan $2 \theta=36,7189$ dengan $h k l=(002)$. Sedangkan nilai $P$ terendah terdapat pada suhu sintering $825^{\circ} \mathrm{C}$

didapat dari $2 \theta=21,7089$ dengan $h k l=(006)$, dan $2 \theta=28,978$ dengan $h k l=(008)$. Nilai $P$ pada suhu sintering $835^{\circ} \mathrm{C}$ sebesar $18,25 \%$ didapat dari $2 \theta=17,2051$ dengan $h k l=(006), 2 \theta=21,8456$ dengan $h k l=(004), 2 \theta=$ 23,0275 dengan $h k l=(008)$, dan $2 \theta=36,7367$ dengan $h k l=(00 \underline{10})$. Nilai $P$ pada suhu sintering $840^{\circ} \mathrm{C}$ sebesar $12,43 \%$ didapat dari $2 \theta=17,0988$ dengan $h k l=(006)$, dan $2 \theta=22, \overline{9592}$ dengan $h k l=(008)$.

\subsection{Hasil Analisis X-Ray Diffraction (XRD) BPSCCO-2212}

Hasil analisis XRD BPSCCO-2212 menunjukkan banyak fase impuritas yang terbentuk dikarenakan banyaknya unsur yang terurai atau berikatan dengan unsur lain sehingga menyebabkan banyaknya fase yang terbentuk. Hasil analisis XRD BPSCCO-2212 ditunjukkan pada Gambar 3. 
Karo P K, Ramadhan R P, Suprihatin, dan Yulianti Y, 2021, Analisis Pertumbuhan Fase Superkonduktor BSCCO2212 dan BPSCCO-2212 Akibat Variasi Suhu Sintering Menggunakan Metode Pencampuran Basah, Journal of Energy, Material, and Instrumentation Technology, Vol. 2, No. 4, 2021

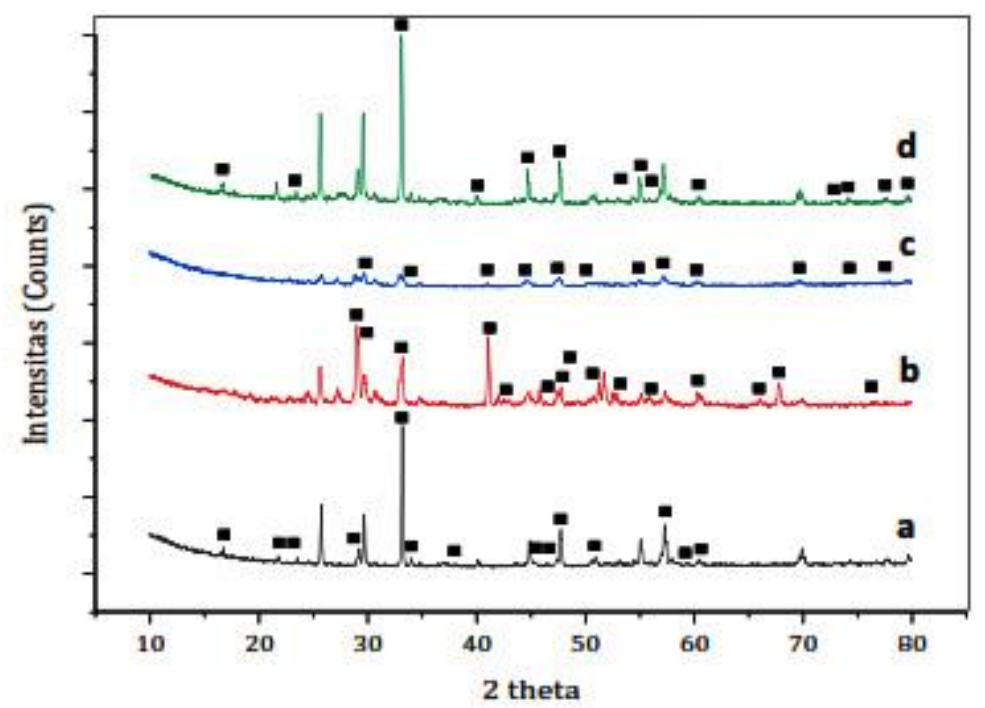

Gambar 3. Hasil analisis XRD sampel BPSCCO-2212 menggunakan HSP ( $\mathbf{m}=$ fase BSCCO-2212). a (BPSCCO2212-825), b (BPSCCO-2212-830, c (BPSCCO-2212-835), dan d (BPSCCO-2212-840).

Hasil perhitungan fraksi volume $(F v)$, impuritas (I) dan derajat orientasi $(P)$ BPSCCO-2212 ditunjukkan pada Tabel 4.

Tabel 4. Perhitungan tingkat kemurnian fase $\mathrm{BPSCCO}-2212$ (doping $\mathrm{Pb}=0,2 \mathrm{~mol}$ ) akibat variasi suhu sintering

\begin{tabular}{ccccc}
\hline Kode Sampel & Suhu $\left({ }^{\circ} \mathbf{C}\right)$ & Fraksi Volume (\%) & Impuritas (\%) & $\begin{array}{c}\text { Derajat Orientasi } \\
\text { (\%) }\end{array}$ \\
\hline BPSCCO-2212-825 & 825 & 51 & 49 & 9,48 \\
BPSCCO-2212-830 & 830 & 52,59 & 47,41 & 43,49 \\
BPSCCO-2212-835 & 835 & 54,53 & 45,47 & 23,06 \\
BPSCCO-2212-840 & 840 & 49,43 & 50,57 & 24,28 \\
\hline
\end{tabular}

Berdasarkan hasil perhitungan yang diperoleh terjadi peningkatan nilai fraksi volume hingga mencapai suhu $835^{\circ} \mathrm{C}$ kemudian terjadi penurunan pada suhu $840^{\circ} \mathrm{C}$ seperti yang ditunjukkan pada Tabel 4 .

Pada sampel BPSCCO-2212 nilai $F v$ mencapai titik optimum pada suhu sintering $835^{\circ} \mathrm{C}$ sebesar $54,53 \%$ dan I sebesar 45,47\% dengan impuritas merupakan fase $\mathrm{Bi}_{2} \mathrm{Sr}_{2} \mathrm{CuO}_{\mathrm{x}}, \mathrm{CaCuO}_{2}, \mathrm{CuO}, \mathrm{Ca}_{4} \mathrm{O}_{4}$ dan $\mathrm{Sr}_{2} \mathrm{Cu}_{2} \mathrm{O}_{3}$. Sedangkan nilai $F v$ terendah terdapat pada suhu sintering $840^{\circ} \mathrm{C}$ sebesar $49,43 \%$ dan $I$ sebesar $50,57 \%$ dengan impuritas merupakan fase $\mathrm{CaCuO}_{2}, \mathrm{CaBi}_{2} \mathrm{O}_{4}, \mathrm{Sr}_{8,5} \mathrm{Bi}_{6} \mathrm{Ca}_{2,5} \mathrm{O}_{22}$ dan $\mathrm{Bi}_{2} \mathrm{Sr}_{2} \mathrm{Ca}_{2} \mathrm{Cu}_{3} \mathrm{O}_{\mathrm{x}}$. Suhu sintering $825^{\circ} \mathrm{C}$ menghasilkan nilai $F v$ sebesar $51 \%$ dan $I$ sebesar $49 \%$ dengan impuritas merupakan fase $\mathrm{Bi}_{2} \mathrm{Sr}_{2} \mathrm{CuO}_{\mathrm{x}}, \mathrm{CaCuO}_{2}, \mathrm{CuO}_{2}$, dan $\mathrm{Bi}$. Suhu sintering $830^{\circ} \mathrm{C}$ menghasilkan $F v$ sebesar $52,59 \%$ dan $I$ sebesar $45,47 \%$ dengan impuritas merupakan fase $\mathrm{CaCuO}_{2}, \mathrm{CuO}, \mathrm{CaSr}_{3} \mathrm{Bi}_{2} \mathrm{O}_{89}$ dan , $\mathrm{Ca}_{4} \mathrm{O}_{4}$.

Kemudian diperoleh juga hasil perhitungan derajat orentasi berupa nilai puncak $h=k=0$ dan $l$ merupakan bilangan genap. Hasil perhitungan $P$ dari masing - masing sampel menghasilkan nilai $P$ tertinggi pada suhu sintering $830^{\circ} \mathrm{C}$ sebesar $43,49 \%$ didapat dari $2 \theta=29,004$ dengan $h k l=(008), 2 \theta=29,1927$ dengan $h k l=(00 \underline{10}), 2 \theta$ $=47,3969$ dengan $h k l=(00 \underline{16})$, dan $2 \theta=60,2959$ dengan $h k l=(00 \underline{20})$. Sedangkan nilai $P$ terendah terdapat pada suhu sintering $825^{\circ} \mathrm{C}$ sebesar 9,48\% didapat dari $2 \theta=29,2252$ dengan $h k l=(00 \underline{10})$, dan $2 \theta=47,3761$ dengan $h k l$ $=(00 \underline{16})$. Nilai $P$ pada suhu sintering $835^{\circ} \mathrm{C}$ sebesar $23,06 \%$ didapat dari $2 \theta=30,6706$ dengan $h k l=(004), 2 \theta=$ 34,7827 dengan $h k l=(0012)$, dan $2 \theta=60,1799$ dengan $h k l=(0020)$. Nilai $P$ pada suhu sintering $840^{\circ} \mathrm{C}$ sebesar $24,28 \%$ didapat dari $2 \theta=21,6496$ dengan $h k l=(006), 2 \theta=25,0497$ dengan $h k l=(002), 2 \theta=29,0685$ dengan $h k l=$ (008), $2 \theta=36,7202$ dengan $h k l=(00 \underline{10})$ dan $2 \theta=60,3657$ dengan $h k l=(00 \underline{20})$.

\subsection{Pengaruh Penambahan Doping Pb terhadap Tingkat Kemurnian Fase Bi-2212}

Berdasarkan analisis XRD sampel BSCCO-2212 dan BPSCCO-2212, menunjukkan bahwa penambahan doping $\mathrm{Pb} \mathrm{0,2} \mathrm{mol} \mathrm{berpengaruh} \mathrm{terhadap} \mathrm{tingkat} \mathrm{kemurnian} \mathrm{fase} \mathrm{BI-2212.} \mathrm{Perbandingan} \mathrm{tingkat} \mathrm{kemurnian} \mathrm{fase}$ superkonduktor BSCCO-2212 dan BPSCCO-2212 diukur berdasarkan fraksi volume, impuritas dan derajat orientasi. Perbandingan fraksi volume superkonduktor BSCCO-2212 dan BPSCCO-2212 ditunjukkan pada Gambar 4. 


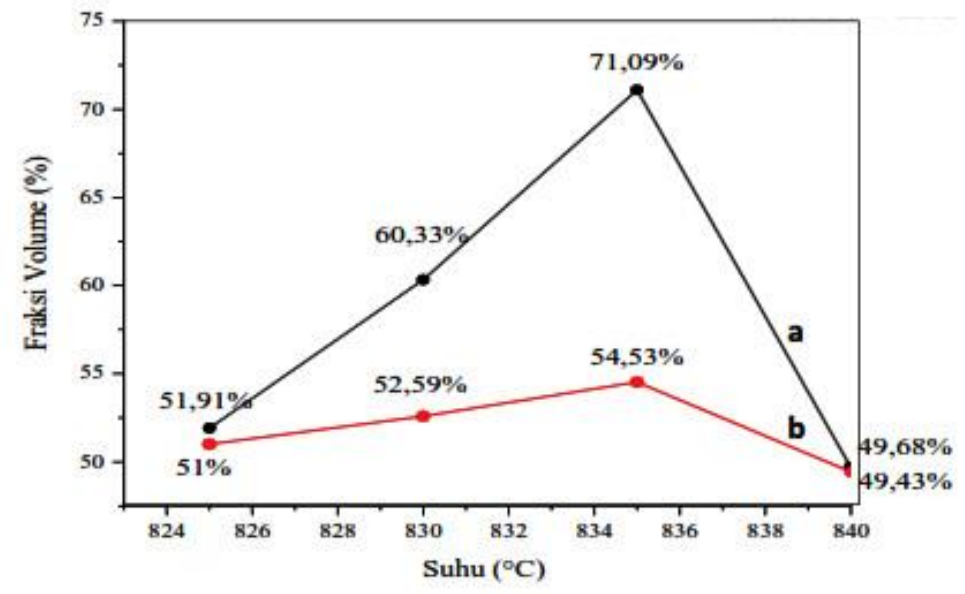

Gambar 4. Perbandingan fraksi volume a BSCCO-2212 (tanpa doping) dan b BPSCCO-2212 (doping Pb = 0,2 mol) akibat variasi suhu sintering.

Berdasarkan Gambar 4, sampel BSCCO-2212 memiliki fraksi volume yang lebih tinggi daripada BPSCCO2212 , dengan suhu optimum pada suhu $835^{\circ} \mathrm{C}$. Fraksi volume tertinggi pada BSCCO-2212 sebesar $71,09 \%$, sedangkan pada BPSCCO-2212 sebesar 54,53\%.

Rendahnya nilai fraksi volume BPSCCO-2212 daripada BSCCO-2212 menunjukkan bahwa penambahan doping $\mathrm{Pb}$ akan menurunkan nilai fraksi volume. Menurut Nurmalita (2011), hal ini disebabkan fase 2212 yang terbentuk dengan bidang selain $(\mathrm{OO} l$ ) pada sampel dengan doping $\mathrm{Pb}$ lebih banyak dibandingkan sampel tanpa $\mathrm{Pb}$. Penurunan fraksi volume juga disebabkan oleh sifat pelelehan yang ingkongruen dari bahan penyusun dan penambahan doping $\mathrm{Pb}$ akan menurunkan konsentrasi $\mathrm{Cu}$ dan $\mathrm{Ca}$ sehingga akan meningkatkan impuritas baik berupa fase superkonduktif maupun nonsuperkonduktif. Hal ini juga sesuai dengan eksperimen yang dilaporkan sebelumnya oleh Kishida et al (1995), meskipun dengan metode yang berbeda.

Berdasarkan derajat orientasi, perbandingan tingkat kemurnian fase BSCCO-2212 dan BPSCCO-2212 akibat variasi suhu sintering ditunjukkan pada Gambar 5.

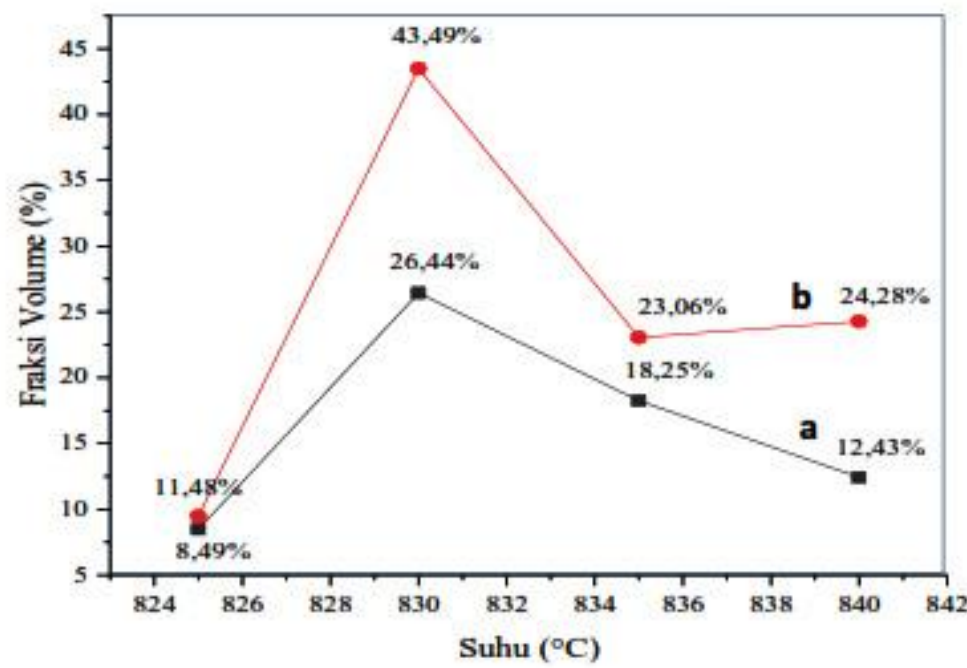

Gambar 5. Perbandingan derajat orientasi a BSCCO-2212 (tanpa doping) dan b BPSCCO-2212 (doping Pb $=0,2$ mol) akibat variasi suhu sintering

Berdasarkan Gambar 5, sampel BPSCCO-2212 memiliki nilai derajat orientasi yang lebih tinggi daripada BSCCO-2212 dengan suhu optimum pada $830^{\circ} \mathrm{C}$. Derajat orientasi tertinggi pada BPSCCO-2212 sebesar 43,49\%, sedangkan pada BSCCO-2212 sebesar 26,44\%.

Nilai derajat orientasi BPSCCO-2212 lebih tinggi daripada BSCCO-2212 menunjukkan bahwa doping $\mathrm{Pb}$ dapat membantu pembentukan kristal sehingga memiliki susunan kristal yang lebih terarah dan ruang kosong semakin sedikit.

Berdarkan nilai fraksi volume dan derajat orientasi, ditunjukkan bahwa sampel BPSCCO-2212 memiliki tingkat kemurnian fase yang lebih baik daripada sampel BSCCO-2212. 
Karo P K, Ramadhan R P, Suprihatin, dan Yulianti Y, 2021, Analisis Pertumbuhan Fase Superkonduktor BSCCO2212 dan BPSCCO-2212 Akibat Variasi Suhu Sintering Menggunakan Metode Pencampuran Basah, Journal of Energy, Material, and Instrumentation Technology, Vol. 2, No. 4, 2021

\section{Kesimpulan}

Berdasarkan hasill penelitian yang telah dilakukan, diperoleh beberapa kesimpulan yaitu seiring peningkatan suhu sintering, $F v$ superkonduktor BSCCO-2212 meningkat hingga mencapai titik optimum pada suhu sintering $835^{\circ} \mathrm{C}$ kemudian mengalami penurunan pada suhu sintering $840^{\circ} \mathrm{C}, \mathrm{Fv}$ tertinggi pada suhu $835^{\circ} \mathrm{C}$ yaitu sebesar $71,09 \%$, Fv terendah pada suhu $840^{\circ} \mathrm{C}$ sebesar $49,68 \%$. Nilai derajat orientasi superkonduktor BSCCO-2212 memiliki $P$ tertinggi pada suhu $830^{\circ} \mathrm{C}$ yaitu sebesar $23,38 \%, P$ terendah pada suhu $825^{\circ} \mathrm{C}$ sebesar $11,48 \%$.

Pada superkonduktor sistem BPSCCO-2212, seiring peningkatan suhu sintering, $F v$ meningkat hingga mencapai titik optimum pada suhu sintering $835^{\circ} \mathrm{C}$ kemudian mengalami penurunan pada suhu sintering $840^{\circ} \mathrm{C}$, $F v$ tertinggi pada suhu $835^{\circ} \mathrm{C}$ yaitu sebesar $54,53 \%, F v$ terendah pada suhu $840^{\circ} \mathrm{C}$ sebesar 49,43 . Pada superkonduktor sistem BPSCCO-2212, memiliki $P$ tertinggi pada suhu $830^{\circ} \mathrm{C}$ yaitu sebesar $43,49 \%, P$ terendah pada suhu $825^{\circ} \mathrm{C}$ sebesar $9,48 \%$.

Nilai optimum fraksi volume BSCCO-2212 lebih tinggi dari pada BPSCCO-2212. Sedangkan nilai optimum derajat orientasi BPSCCO-2212 lebih tinggi dari pada BSCCO-2212

\section{Daftar Pustaka}

W. D. Callister and D. G. Rethwisch, "Materials and engineering 9th edition," New York: Jonh Wiley and Sons Inc, 2014.

Suprihatin, "Pengaruh Variasi Suhu Sintering dalam Sintesis Superkonduktor Bi-2212 dengan Doping $\mathrm{Pb}$ (BPSCCO-2212) pada Suhu Kalsinasi 790 ${ }^{\circ}$," Pros. Semin. Nas. Sains dan Teknologi-II, pp. 67-73, 2008.

H. Fallaharani, B. Saeid, S. Arman, S. Daniela, T. Frances, M. Davide, and R. Nastaran, " The Influence of Head Treatment on the Microstructure, Flux Pinning and Magnetic Properties of Bulk BSCCO Samples Prepared by Sol-Gel Route," Ceramics International, vol. 128, no. 12, pp. 1-25, 2017.

I. Marhaendrajaya, "Eksperimen Pembentukan Kristal BPSCCO-2223 dengan Metode Lelehan," Berkala Fisika, vol. 4, no. 2, pp. 33-40, 2001.

R. M. Fauzi, " Pertumbuhan Fase Superkonduktor Bi-2223 dengan Variasi Doping Pb (BPSCCO-2223) pada Kadar $\mathrm{Ca}=2,10$ dan Suhu Sintering $855^{\circ} \mathrm{C}, "$ Universitas Lampung, Bandar Lampung, 2017.

L. Rohmawati and Darminto, " Nanokristalisasi Superkonduktor $(\mathrm{Bi}, \mathrm{Pb})_{2} \mathrm{Sr}_{2} \mathrm{CaCu}_{2} \mathrm{O}_{8+\mathrm{d}}$ dengan Metode Pencampuran Basah," Berkala Fisika, vol. 4, no. 1 \& 2, pp. 22-26, 2012.

Herlyn, "Pengaruh Lama Pemanasan Terhadap Konduktivitas Normal Superkonduktor Overpofed Pb $(\mathrm{BiPb})_{2} \mathrm{Sr}_{2} \mathrm{Ca}_{2} \mathrm{Cu}_{3} \mathrm{O}_{10}$ dengan Metode Melt-Textured," Universitas Negeri Medan, Medan, 2008.

H. Raffy, " BSCCO high-Tc superconducting films," Paris: Woodhead Publishing Limited, 2011.

I. Shimono, "Preparation of Bi-Pb-Sr-Ca-Cu-O Superconductor by the Citrate Method," Journal of the Ceramic Society of Japan, vol. 101, no. 1177, pp. 1044-1050, 1993.

S. Siswayanti, B. Agung, L. Amirul, M. A. Ikhlasul, Hendrik, and Pius, "Sintesis Pelet Bi-Sr-Ca-Cu-O dengan Suhu Sintering Rendah dan Analisa Sifat Superkonduktivitasnya," Pros. Sem. Material Metalurgi, pp. 227-231, 2015.

D. A. Cardwell and D. S. Ginley, "Handbook of superconductor materials," Florida: CRC Press, 2003.

Suprihatin, R. Pratiwi, and Syafriadi, " Variasi doping Pb Terhadap Pertumbuhan Fase Bahan Superkonduktor Bi2212 pada Kadar Ca 1,10 dan Suhu Sintering $830^{\circ}$ C," Jurnal Teori dan Fisika, vol. 5, no. 2, pp. 187-194, 2017.

D. B. Curie and A. M. Forest, " Crystal and High Tc Superconductor in the System $\mathrm{Gd}_{1} \mathrm{Ba}_{2-\mathrm{x}} \mathrm{Sr}_{\mathrm{x}} \mathrm{Cu}_{3} \mathrm{O}_{7-\mathrm{x}}$," Solid State Communications, vol. 66, no. 7, pp. 715-718, 1998.

M. Roumie, S. Marhaba, R. Awad, M. Kork, I. Hasan, and R. Mawassi, "Effect of $\mathrm{Fe}_{2} \mathrm{O}_{3}$ Nano-Oxide Addition on the Superconducting Properties of the (Bi,Pb)-2223 Phase," Journal of Superconductivity and Novel Magnetism. vol. 27 , no. 1, pp. 143-,53. 2014.

Nurmalita, "Sintesis Kristal Superkonduktor dengan Metode Melt Mextured Growth," Institut Teknologi Bandung, Bandung, 2002.

P. Strobel, J. Toledano, D. Morin, J. Schneck, G. Vacquier, O. Monnereau, J. Primot, and T. Fournier, " Phase Diagram of the System $\mathrm{Bi}_{1,6} \mathrm{~Pb}_{0,4} \mathrm{Sr}_{2} \mathrm{CuO}_{6}-\mathrm{CaCuO}_{2}$ Between $825^{\circ} \mathrm{C}$ and $1100^{\circ} \mathrm{C}$," Physica $\mathrm{C}$, vol. 201, pp. 2142, 1992.

H. Liu, L. Liu, H. Yu, Y. Zhang, and Z. Jin, "Optimization of the Composition for Synthesizing the High-Tc Phase in $\mathrm{Bi}(\mathrm{Pb}) \mathrm{SrCaCuO}$ System," Journal of Materials Science, vol. 34, no. 17, pp. 4329-4332, 1999. 
W. Miller, K. Borowko, M. Gazda, S. Stizza, and R. Natali, " Superconducting Properties of BiPbSrCaCuO and BiSrCaCuO Glass-Ceramics," Acta Physica Polonica A, vol. 109, no. 4, pp.627-631, 2006.

S. Kishida, T. Yumoto, S. Nakhasima, H. Tokutaka, K. Fujimura, "Effect of Temperatures and Periods Melting on Growth of $\mathrm{Bi}_{2} \mathrm{Sr}_{2} \mathrm{CaCu}_{2} \mathrm{O}_{\mathrm{y}}$ Single Crystal, Journal of Growth, 153, pp. 146-150, 1995. 